\title{
Protocol
}

\section{Isolating Phagosomes from Tissue Culture Cells}

\author{
Paul R. Pryor ${ }^{1}$ and Adam P. Rofe \\ Centre for Immunology and Infection, Hull York Medical School and Department of Biology, University of York, \\ York YO10 5DD, United Kingdom
}

Phagocytosis is the process by which receptors at the plasma membrane are used to engulf a particle such as a bacterium, parasite, or dead cell. Phagosomes can be isolated from tissue culture cells by various centrifugation methods, including the use of differential density gradients or sucrose step gradients, but these methods are time-consuming or otherwise difficult. We describe here a protocol that avoids centrifugation and relies instead on the uptake of magnetic beads to rapidly isolate the phagosomal compartment from tissue culture cells.

\section{MATERIALS}

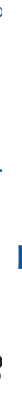

It is essential that you consult the appropriate Material Safety Data Sheets and your institution's Environmental Health and Safety Office for proper handling of equipment and hazardous materials used in this protocol.

RECIPES: Please see the end of this protocol for recipes indicated by $<R>$. Additional recipes can be found online at http://cshprotocols.cshlp.org/site/recipes.

Reagents

Binding medium for phagosomes (prechilled to $4^{\circ} \mathrm{C}$ ) $<\mathrm{R}>$

Cultured cells

We recommend the use of tissue culture cells, preferably a professional phagocytic cell such as a monocyte, neutrophil, or macrophage, although most cells can undergo phagocytosis. This protocol is optimized for the use of J774.2 mouse macrophages.

STM fractionation buffer (prechilled to $4^{\circ} \mathrm{C}$ ) $<\mathrm{R}>$

Tissue culture medium

For 1774.2 cells, we use Dulbecco's modified Eagle's medium (DMEM) supplemented with 10\% (v/v) fetal calf serum (FCS).

Equipment

Benchtop centrifuge (refrigerated) with rotor to accommodate 3.5-cm dishes (e.g., Eppendorf 5810R with rotor A-4-62)

Cell culture dishes (six-well)

Cell homogenizer with ball bearings (from Isobiotec or EMBL Workshop)

Incubator for cell tissue culture

Magnet (e.g., DynaMag-2 from Invitrogen/Life Technologies)

Magnetic beads (Promag Magnetic Microspheres [3.16- $\mu \mathrm{m}$ ], ProMag 3 Series, Bangs Laboratories, Inc.)

\footnotetext{
${ }^{1}$ Correspondence: paul.pryor@york.ac.uk

(c) 2014 Cold Spring Harbor Laboratory Press

Cite this protocol as Cold Spring Harb Protoc; doi:10.1101/pdb.prot074468
} 
Microscope (e.g., tissue culture microscope such as Motic Type 101M)

Rubber cell scraper

Syringes $(1 \mathrm{~mL})$

The volumes in this protocol are based on the use of one well of a six-well dish of J774.2 macrophages per isolation.

1. Seed the tissue culture cells $\left(1 \times 10^{6} \mathrm{~J} 774.2\right.$ macrophages per well $)$. Place the dish in a tissue culture incubator for $24 \mathrm{~h}$ with the appropriate medium; use $2 \mathrm{~mL}$ of DMEM supplemented with $10 \%$ FCS for each well of J774.2 cells.

2. On the following day, rinse the cells gently three times using $2 \mathrm{~mL}$ of ice-cold binding medium for each wash. Chill the cells by incubating them for $15 \mathrm{~min}$ at $4^{\circ} \mathrm{C}$.

J774.2 cells are semiadherent; therefore, care must be taken when removing the medium and washing the cells in this and subsequent steps.

3. Prepare $2 \mathrm{~mL}$ of binding medium containing magnetic beads at a ratio of 3 beads per cell. Replace the binding medium in the dish with the medium containing magnetic beads.

4. Deliver the beads onto the cells by centrifuging them at $200 \mathrm{~g}$ for $5 \mathrm{~min}$ at $4^{\circ} \mathrm{C}$.

5. Incubate the cells for $1 \mathrm{~h}$ at $4^{\circ} \mathrm{C}$ to allow the beads to bind to the cells.

6. Wash the cells three times with $2 \mathrm{~mL}$ of binding medium.

7. Replace the binding medium with $2 \mathrm{~mL}$ of prewarmed medium, and place the cells into a tissue culture incubator.

Phagocytosis proceeds at $37^{\circ} \mathrm{C}$, and the length of the incubation time very much depends on which phagocytic compartment is to be isolated. In this study, $2 \mathrm{~h}$ is sufficient for the isolation primarily of phagolysosomes, whereas shorter incubations will be necessary to isolate early and late phagocytic compartments. See Discussion.

8. Remove as much medium as possible by decanting or aspiration, and then harvest the cells by scraping them with a rubber cell scraper into $1 \mathrm{~mL}$ of ice-cold STM.

The final volume will be $>1 \mathrm{~mL}$ because of the presence of the cells and any remaining medium.

From this point onward, keep all solutions at $4^{\circ} \mathrm{C}$, and, if possible, work in a cold room with the temperature controlled to $4^{\circ} \mathrm{C}$.

9. Homogenize the cells.

i. Set the specific clearance of the ball-bearing homogenizer to $12 \mu \mathrm{m}$.

ii. Mount two 1-mL syringes on the chamber, and transfer the cells into one of these.

iii. Pass the cells through the chamber 20 times using the $1-\mathrm{mL}$ syringes.

iv. Visually check the homogenates under a microscope to ensure that no intact cells remain.

10. Incubate the homogenate on a magnet for $5 \mathrm{~min}$ at $4^{\circ} \mathrm{C}$, remove the supernatant, and then resuspend the phagosomes in $1 \mathrm{~mL}$ of STM. Repeat this sequence two more times to isolate and wash the phagosomes.

Phagosomes can finally be suspended in STM in a volume that is appropriate (volumes $<1 \mathrm{~mL}$ ). The sample can be stored at $\leq-80^{\circ} \mathrm{C}$, but the latency will be reduced. The stored sample can be a source of protein for analyses, but the organelle will be less likely to be functional.

Here we describe the use of magnetic beads to rapidly isolate phagosomes. The phagosomes isolated with this protocol are intact and can be used in in vitro fusion assays or can be further characterized (e.g., by proteomics analysis). Traditional phagosome-isolation methods are based on centrifugation. A relatively pure phagosomal population can be isolated by differential density-gradient centrifugation. This approach, however, can be time-consuming, because the density of the phagosomal com- 
P.R. Pryor and A.P. Rofe

partment is the same as for other organelles. Another centrifugation method relies on the uptake of latex beads by phagosomes. This approach circumnavigates the problem of density, as latex beadcontaining phagosomes are buoyant relative to other organelles and can be readily separated from them on sucrose gradients (Rabinowitz et al. 1992; Desjardins et al. 1994). But because sucrose can place osomotic stress on organelles, the use of an iso-osmotic centrifugation medium such as Nycodenz or Ficoll is preferable for isolating phagosomes if they are to be used in functional assays. Both magnetic and latex beads are commercially available in forms coupled to reactive groups that allow molecules found in intracellular pathogens to become attached to their surfaces. These reactive groups facilitate the analysis of the effects of these molecules on the maturation of the phagosome (Osanya et al. 2011). It is possible to purify bacteria-containing phagosomes (Alvarez-Dominguez et al. 1996), but evaluating the contribution of individual bacterial proteins and lipids to a maturing phagosome becomes complex unless these individual factors are deleted from the bacterium.

When isolating different phagocytic compartments by varying the incubation period for phagocytosis (see Step 7), we routinely use western blotting to identify proteins associated with a particular stage of the isolated phagosomes. For example, the proteins EEA1, Rab7, and LAMP1 are indicators of early phagosomes, late phagosomes, and phagolysosomes, respectively. However, because of the large extent of heterogeneity, the population of isolated phagosomes represents only the "average" phagosomal compartment at that time point. If we compare samples from different time points, then we routinely normalize the samples, based either on protein content or on optical density of the sample at $600 \mathrm{~nm}$.

It should be noted that the rate of phagocytosis depends on factors such as the cell type, the size of the particle (Roberts and Quastel 1963), the surface chemistry of the particle (Tabata and Ikada 1988), and the shape of the particle (Paul et al. 2013). Therefore, the phagocytic compartment of a hydrophobic, spherical 1- $\mu$ m latex bead should not be compared with the phagosomal compartment surrounding a hydrophilic, rod-shaped bacterium of $2 \mu \mathrm{m}$.

\section{Binding Medium for Phagosomes}

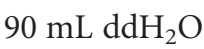

$1 \mathrm{~mL}$ RPMI medium $(10 \times)$

$1 \mathrm{~mL}$ BSA $(20 \%[\mathrm{w} / \mathrm{v}])$

1 mL HEPES ( $\mathrm{pH} 8.0)$

Combine the above ingredients, adjust the $\mathrm{pH}$ to 7.4 with $\mathrm{NaOH}$, and then add $\mathrm{ddH}_{2} \mathrm{O}$ to a final volume of $100 \mathrm{~mL}$.

\section{STM Fractionation Buffer}

$250 \mathrm{~mm}$ sucrose

$1 \mathrm{~mm} \mathrm{MgCl} 2$

10 mм TES (2-[[1,3-dihydroxy-2-(hydroxymethyl)propan-2-yl]amino]ethanesulfonic acid) ( $\mathrm{pH} 7.4)$

Store the buffer at $-20^{\circ} \mathrm{C}$, and keep on ice until use.

\section{REFERENCES}

Alvarez-Dominguez C, Barbieri AM, Beron W, Wandinger-Ness A, Stahl PD. 1996. Phagocytosed live Listeria monocytogenes influences Rab5regulated in vitro phagosome-endosome fusion. J Biol Chem 271: 13834-13843.

Desjardins M, Huber LA, Parton RG, Griffiths G. 1994. Biogenesis of phagolysosomes proceeds through a sequential series of interactions with the endocytic apparatus. J Cell Biol 124: 677-688.
Osanya A, Song EH, Metz K, Shimak RM, Boggiatto PM, Huffman E, Johnson C, Hostetter JM, Pohl NL, Petersen CA. 2011. Pathogenderived oligosaccharides improve innate immune response to intracellular parasite infection. Am J Pathol 179: 1329-1337.

Paul D, Achouri S, Yoon YZ, Herre J, Bryant CE, Cicuta P. 2013. Phagocytosis dynamics depends on target shape. Biophys J 105: 11431150 . 
Rabinowitz S, Horstmann H, Gordon S, Griffiths G. 1992. Immunocytochemical characterization of the endocytic and phagolysosomal compartments in peritoneal macrophages. J Cell Biol 116: 95-112.

Roberts J, Quastel JH. 1963. Particle uptake by polymorphonuclear leucocytes and Ehrlich ascites-carcinoma cells. Biochem J 89: 150-156.
Tabata Y, Ikada Y. 1988. Effect of the size and surface charge of polymer microspheres on their phagocytosis by macrophage. Biomaterials 9: $356-362$. 


\section{Isolating Phagosomes from Tissue Culture Cells}

Paul R. Pryor and Adam P. Rofe

Cold Spring Harb Protoc; doi: 10.1101/pdb.prot074468

\begin{tabular}{rc}
\hline $\begin{array}{r}\text { Email Alerting } \\
\text { Service }\end{array}$ & Receive free email alerts when new articles cite this article - click here. \\
\hline $\begin{array}{c}\text { Subject } \\
\text { Categories }\end{array}$ & $\begin{array}{c}\text { Browse articles on similar topics from Cold Spring Harbor Protocols. } \\
\text { Cell Biology, general (1382 articles) } \\
\text { Preparation of Cellular and Subcellular Extracts (104 articles) } \\
\text { Subcellular Fractionation (88 articles) }\end{array}$ \\
\hline
\end{tabular}

